\title{
Teaching NeuroImages: Acute stroke captured on EEG in the ICU
}

\section{Visual and quantitative analysis}

Brad K. Kamitaki, MD, Bin Tu, MD, PhD, Alexandra S. Reynolds, MD, and Catherine A. Schevon, MD, PhD

Neurology ${ }^{\circledR}$ 2019;92:e626-e627. doi:10.1212/WNL.0000000000006882
Correspondence

Dr. Kamitaki

brad.kamitaki@rutgers.edu

Figure 1 CT perfusion imaging prior to stroke
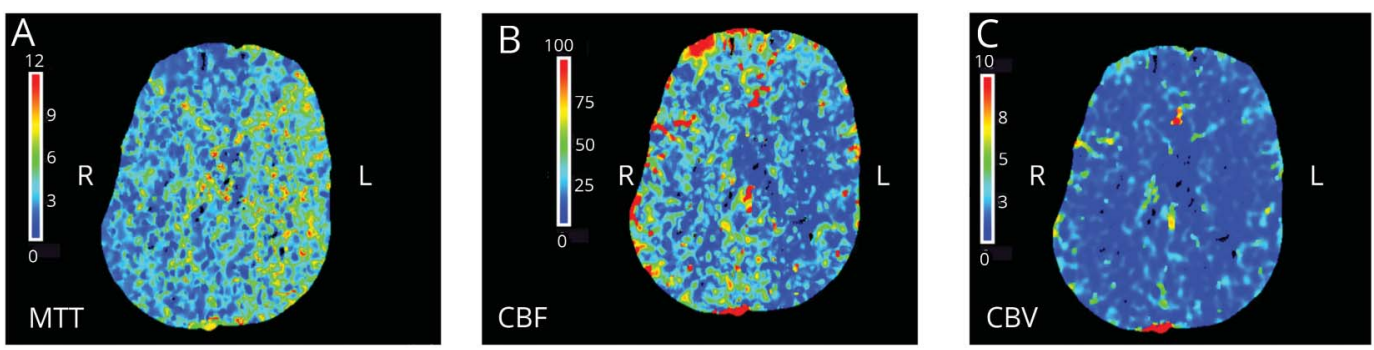

(A) Increased mean transit time, (B) decreased cerebral blood flow, and (C) unchanged cerebral blood volume in the left middle cerebral artery territory indicate an area at risk for infarct.

A 56-year-old man underwent a complicated left carotid endarterectomy, ultimately resulting in complete arterial ligation. Postoperative examination was nonfocal; CT perfusion noted vulnerability of the left middle cerebral artery (MCA) territory (figure 1, A-C). EEG placed for ischemia monitoring was initially symmetric (figure $2 \mathrm{~A}$ ). Overnight, new left temporal attenuation was noted, a hallmark of cortical ischemia ${ }^{1}$ (figure $2 \mathrm{~B}$ ), which prompted clinical evaluation. Quantitative EEG (QEEG) showed simultaneous decreases in left hemispheric 30-64 $\mathrm{Hz}$ power and amplitude-integrated EEG, followed by delayed reduction in left alpha/delta ratio (figure 2C). Subsequent examination revealed new right hemiparesis, and MRI showed left MCA infarction (figure 2D). Thus, QEEG can detect cerebral ischemia and provide timely information in the intensive care unit. $^{2}$

\section{Study funding}

No targeted funding reported.

\section{Disclosure}

B. Kamitaki is employed by Rutgers-Robert Wood Johnson University, reads inpatient EEG studies, and bills for these studies; he has no other disclosures. B. Tu is employed by Columbia University Medical Center and reads inpatient EEG studies; he has no other disclosures. A. Reynolds reports no disclosures relevant to the manuscript. C. Schevon has research support from NIH (R01 NS084142 and R01 NS095368) and reads inpatient EEG studies in the course of her employment at Columbia University Medical Center and bills for these studies. Go to Neurology.org/N for full disclosures.

\section{MORE ONLINE}

\section{$\rightarrow$ Teaching slides}

links.lww.com/WNL/

A802

From the Department of Neurology (B.K.K.), Rutgers-Robert Wood Johnson Medical School, Piscataway Township, NJ; Department of Neurology (B.T., C.A.S.), Columbia University Medical Center; and Department of Neurosurgery (A.S.R.), Icahn School of Medicine at Mount Sinai, New York, NY.

Go to Neurology.org/N for full disclosures. Funding information and disclosures deemed relevant by the authors, if any, are provided at the end of the article. 

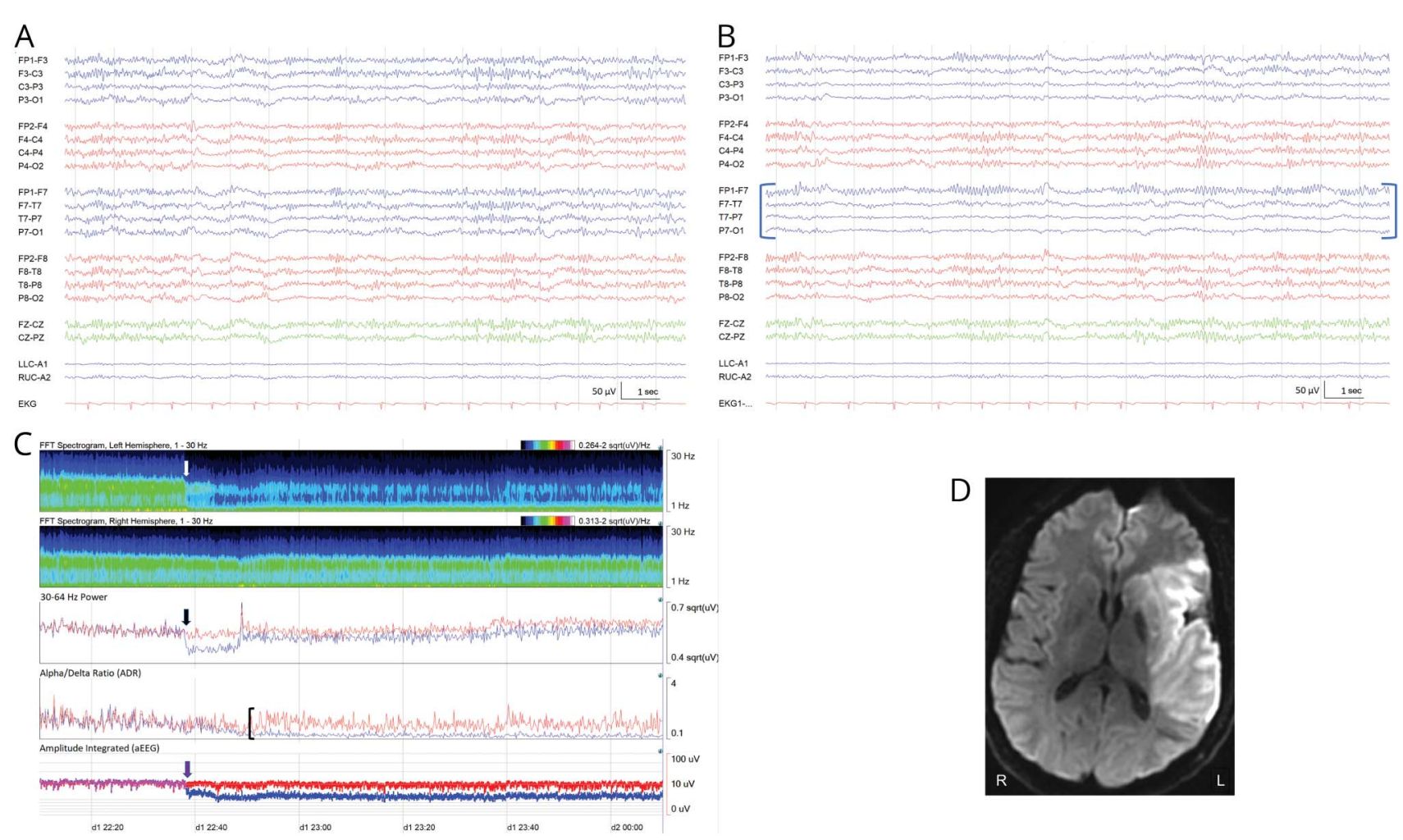

(A) Baseline EEG before presumed time of stroke. (B) EEG: left hemispheric, temporal maximal attenuation of faster frequencies after stroke (brackets). (C) Spectrogram: acute reduction of higher frequency activity over the left hemisphere (white arrow); quantitative EEG (red tracings correspond to the right hemisphere, blue tracings to the left hemisphere): simultaneous reductions in left hemispheric 30-64 Hz power (black arrow) and amplitude-integrated EEG (purple arrow), with delayed drop in alpha/delta ratio 15 minutes later (bracket) (Insight II software, version 11 [Persyst Development Corporation, Prescott, AZ]). (D) MRI brain, diffusion-weighted imaging sequence, shows completed left middle cerebral artery infarct.

\section{Appendix Authors}

\begin{tabular}{|c|c|c|c|}
\hline Name & Location & Role & Contribution \\
\hline $\begin{array}{l}\text { Brad K. } \\
\text { Kamitaki, MD }\end{array}$ & $\begin{array}{l}\text { Rutgers-Robert } \\
\text { Wood Johnson } \\
\text { Medical School }\end{array}$ & Author & $\begin{array}{l}\text { Case report design and } \\
\text { concept, interpretation } \\
\text { of EEG data, drafted the } \\
\text { manuscript for } \\
\text { intellectual content }\end{array}$ \\
\hline $\begin{array}{l}\text { Bin Tu, } \\
\text { MD, PhD }\end{array}$ & $\begin{array}{l}\text { Columbia } \\
\text { University } \\
\text { Medical Center }\end{array}$ & Author & $\begin{array}{l}\text { Major role in acquisition } \\
\text { and interpretation of EEG } \\
\text { and quantitative EEG } \\
\text { data }\end{array}$ \\
\hline $\begin{array}{l}\text { Alexandra S. } \\
\text { Reynolds, MD }\end{array}$ & $\begin{array}{l}\text { Icahn School of } \\
\text { Medicine at } \\
\text { Mount Sinai }\end{array}$ & Author & $\begin{array}{l}\text { Major role in acquisition } \\
\text { and interpretation of } \\
\text { neuroimaging data }\end{array}$ \\
\hline $\begin{array}{l}\text { Catherine A. } \\
\text { Schevon, } \\
\text { MD, PhD }\end{array}$ & $\begin{array}{l}\text { Columbia } \\
\text { University } \\
\text { Medical Center }\end{array}$ & Author & $\begin{array}{l}\text { Case report design and } \\
\text { concept, interpretation } \\
\text { of EEG data, critical } \\
\text { revision of the } \\
\text { manuscript for } \\
\text { intellectual content }\end{array}$ \\
\hline
\end{tabular}

\section{References}

1. Jordan KG. Emergency EEG and continuous EEG monitoring in acute stroke. J Clin Neurophysiol 2004;21:341-352.

2. Foreman B, Claassen J. Quantitative EEG for the detection of brain ischemia. Crit Care 2012;16:216. 


\section{Neurology}

\section{Teaching NeuroImages: Acute stroke captured on EEG in the ICU: Visual and quantitative analysis}

Brad K. Kamitaki, Bin Tu, Alexandra S. Reynolds, et al.

Neurology 2019;92;e626-e627

DOI 10.1212/WNL.0000000000006882

This information is current as of February 4, 2019

\section{Updated Information \&} Services

References

Permissions \& Licensing

Reprints including high resolution figures, can be found at: http://n.neurology.org/content/92/6/e626.full

This article cites 2 articles, 0 of which you can access for free at: http://n.neurology.org/content/92/6/e626.full\#ref-list-1

Information about reproducing this article in parts (figures,tables) or in its entirety can be found online at:

http://www.neurology.org/about/about_the_journal\#permissions

Information about ordering reprints can be found online:

http://n.neurology.org/subscribers/advertise

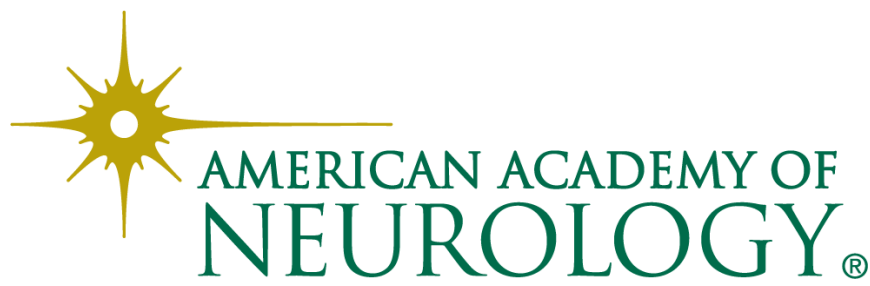

